\title{
PEMIKIRAN HUKUM ISLAM DAN EPISTEMOLOGI TEOLOGI PLURALISTIK
}

\author{
Ramlani Lina Sinaulan \\ Universitas Jayabaya Jakarta, Indonesia \\ E-mail: linasinaulan@gmail.com
}

\begin{abstract}
This article aims to examine the contribution of Islamic epistemology in a pluralistic life within increasing social problems that lead to violence in the name of religion. All people agree that the acts of violence in the name of religion was not justified by religions, including Islam. Islam should provide solution for the establishment of peace, tranquility, and serenity in diversity. Therefore, we should understand Islam as a science, so that the act of violence in the name of religion can be reduced through proper understanding. Pluralistic theology has been studied for long review, although not very deeply. This article, accordingly, describes some key terms in understanding the epistemology of pluralistic theology which is expected to contribute to the development of science that can give realistic solution to the problem of violence in the name of religion.
\end{abstract}

Keywords: Islamic epistemology; pluralistic theology; peace.

\section{Pendahuluan}

Memahami pemikiran Islam (Islamic thought) ibarat secarik atau selembar kertas, di mana antara bagian depan dengan bagian belakang kertas tidak dapat dipisahkan sama sekali, meskipun secara tegas dapat pula dibedakan mana bagian depan dan mana bagian belakang. ${ }^{1}$ Tergantung dari perspektif mana dilihat atau didekati. Sebagai actor, pembela, penyebar, dan penjaga budaya Islam agak sulit membedakan di antara pemikiran Islam yang terus berkembang tersebut. Kondisi demikian membuat sebagian kalangan sulit membedakan mana

\footnotetext{
${ }^{1}$ M. Amin Abdullah, "Ide Pembaruan dalam Filsafat Islam”, dalam Mengenang Y.B. Mangunwijaya Pergulatan Intelektual dalam Era Kegelisahan (Yogyakarta: Kanisius, 2003), 248.
} 
wilayah 'ide', 'gagasan', 'konsep', bahkan 'inspirasi' yang diambil dari sumber epistemologi ${ }^{2}$ Islam, yaitu al-Qur'ân dan al-Sunnah.

Dengan demikian, dari kedudukan dua sumber epistemologi Islam (al-Qur'ân dan al-Sunnah) tersebut, interpretasi tiap manusia yang memiliki akal senantiasa mengalami dinamika dan perdebatan. Dari perdebatan ini pada hakikatnya melahirkan pemikiran-pemikiran yang lebih progresif.

Progresivitas pemikiran keislaman dalam konteks Indonesia harus memperhatikan pertumbuhan, perkembangan, dan kemajemukan. Ini sangat berkait kelindan dengan kondisi Indonesia. Walaupun para ulama belum selesai menerangkan antropologi menurut fisika modern, namun mereka menyadari bahwa ciri dari semua eksistensi selain eksistensi ilahi adalah perubahan (taghayyur). ${ }^{3}$ Karena itu, dalam menghadapi era globalisasi umat Islam memerlukan landasan yang kokoh untuk mempertahankan identitas keislaman mereka dan menghadapi perbauran peradaban dan budaya dan/atau pluralitas multikutural secara positif. ${ }^{4}$

Kesadaran perubahan senantiasa membutuhkan proses dan kerja ekstra di tengah persoalan dominasi paradigma dogmatisme pengetahuan Islam yang begitu kental. Klaim-klaim kebenaran pengetahuan keislaman dari berbagai kelompok Islam terus menggejala dengan sangat menonjol. ${ }^{5}$ Oleh karena itu, jika masih tetap mempertahankan metode yang cenderung mengarah ke dalam 'kejumudan' tersebut, maka pemikiran Islam senantiasa akan jalan di tempat.

2 Dalam lingkungan studi Islam, istilah epistemologi sering dipertukarkan dengan istilah pemikiran. Pemikiran berasal dari kata 'pikir' yang artinya akal, budi, ingatan, angan-angan, sehingga pemikiran berarti proses, cara, perbuatan memikir. Lihat Anwar Mujahidin, "Epistemologi Islam: Kedudukan Wahyu sebagai Sumber Ilmu", Ulumuna: Jurnal Studi Keislaman, Vol. 17, No. 1 (2013), 17.

${ }^{3}$ Nurcholis Madjid, Islam, Doktrin, dan Peradaban: Sebuab Telaah Kritis tentang Masalah Keimanan, Kemanusiaan, dan Kemodernan (Jakarta: Paramadina, 2000), xviii.

4 Muh. Yusuf HM, "Teologi Pluralis Multikultural: Perspektif Qurani”, Jurnal Kontelestualitas, Vol. 24, No. 2 (2008), 69.

${ }^{5}$ Klaim kebenaran (truth claim) pengetahuan Islam berjalan hampir lebih kurang 20 tahun belakangan, di mana corak pemikiran tersebut cenderung lebih kaku dan ahistoris, sehingga menyebabkan pemikiran Islam jalan di tempat, karena kebenaran yang dipandangnya dianggap final. Hal ini menjadikan dunia Islam tidak bisa merespons arus kemodernan dan arus perubahan sosial, kultur politik, dan keagamaan di era modern. Lihat Alim Roswantoro, "Epistemologi Pemikiran Islam M. Amin Abdullah", dalam Islam, Agama-Agama, dan Nilai Kemanusiaan (Yogyakarta: CISForm, 2013), 1. 
Problem pemikiran Islam kontemporer salah satunya pembicaraan mengenai apakah Islam ideal akan terjadi lagi sesudah Rasulullah, sehingga lahir kontradiksi di dalam tubuh Islam dengan banyaknya aliran-aliran keagamaan yang secara kontras mengarah pada egosentrisme antarpemeluknya. Islam sepanjang sejarahnya berinteraksi dan dinilai dari perjalanannya. ${ }^{6}$ Dalam posisi ini, penulis berpendapat bahwa Islam ideal sebagaimana zaman Rasulullah sangat mustahil bisa terwujud. Hal ini terlihat dalam dialektika sejarah yang melahirkan perbedaan pendapat, baik perdebatan metode ijtihâd maupun tajdîd, yang berujung pada jurang pemisah Islam antargolongan dan aliran.

Untuk itu, di tengah persaingan pemikiran yang semakin kompleks, salah satu yang mungkin bisa mendorong terjadinya intropeksi itu adalah kesadaran keumatan yang lebih komprhensif, baik secara historis maupun geografis. Dari kesadaran tersebut pada kesimpulannya dapat mendorong sikap proporsional yang lebih menekankan toleran dan respek di antara sesama maupun berbeda agama. Usaha tersebut dapat terwujud manakala menanggalkan segala sikap agresiatif dan egosentrisme. ${ }^{7}$

Dengan melihat kondisi kemajemukan Indonesia, seyogianya dibutuhkan pemikiran Islam yang lebih "segar" untuk menjawab tantangan zaman yang semakin kompleks. Jika ditarik ke beberapa abad silam, ketika sebagian pola pemikiran dan filsafat Yunani telah ditinjau ulang, dikritisi, dan dipertanyakan ulang keabsahannya oleh pola pikir Aufklarung dan Renaissance, pada gilirannya memunculkan teori-teori baru dalam ilmu-ilmu kealaman dan sosial. Pun dengan ilmu-ilmu keislaman yang seakan terpengaruh oleh pola dan alam pikiran filsafat Yunani masih tetap seperti sediakala. ${ }^{8}$

Ilmu-ilmu keislaman seolah-olah tidak mengenal shifting paradigm keilmuan, sehingga terkesan dalam menginterpretasi kajian keislaman sangat 'teologis'. Gejala ini telah membawa arah baru dalam paradigma keilmuan yang cenderung eksklusif, bersifat final, stationary, dan closed system. ${ }^{9}$ Padahal melihat tantangan zaman saat ini dibutuhkan

${ }^{6}$ Khalil Abdul Karim, "Problematika Pemikiran Islam Kontemporer: Studi Kritis Atas Buku "Solusi Islam; Keharusan dan Keniscayaan Karya Dr. Yusuf AlQardlawi”, dalam Afkar Taswhirul Jurnal Refleksi Pemikiran Kegamaan dan Budaya, Edisi No. 9 Tahun 2000, 100.

${ }^{7}$ Madjid, Islam, Doktrin, 163-164.

8 Abdullah, "Ide Pembaruan", 259.

${ }^{9}$ Fazlur Rahman, Islam (Chicago: The University of Chicago Press, 1979), 31. 
pemikiran Islam yang lebih inklusif, open ended, open system, dan on going proses. Melihat kondisi tersebut, bagi Fazlur Rahman, kebangkitan dan pembaruan menjadi tema sentral dalam setiap skema pemikiran Islam. Kategori tajdîd (pembaruan) dan ijtihâd (berpikir bebas) layak menjadi unsur utama di bawah rubrik pemikiran Islam. ${ }^{10}$

Dengan begitu, dalam melihat tipologi pemikiran Islam yang progresif, patut kiranya penulis menyuguhkan satu mindset baru untuk menelaah dan menghayati pemikiran jauh sebelum Indonesia mendeklarasikan diri menjadi negara majemuk, yaitu terkait dengan teologi pluralistik. Walaupun di era 80-an hingga 90-an, para cendikiawan Muslim, sebut saja Harun Nasution, Nurcholis Madjid, Abdurrahman Wahid, dan lain sebagainya menawarkan pemikiran yang dianggap kala itu melenceng dari kaidah berpikir Islam, pada kenyataanya sampai saat ini pemikiran yang lebih mengutamakan sikap inklusif dapat diterima dengan baik.

Fakta sejarah membuktikan, bahwa wacana teologis menjadi pemicu munculnya konflik sosial politik. Maka patutlah diwaspadai ungkapan dari Thomas Jefferson yang menjelaskan bahwa agamaagama formal akan hancur dalam satu-dua abad dan akan digantikan oleh pandangan yang dianutnya yaitu cita-cita kebebasan beragama, pluralisme dan egalitarianisme. ${ }^{11}$

Kertas kerja ini ingin menyuguhkan gagasan mendasar mengenai epistemologi dari pemikiran teologi pluralistik yang saat ini murni dibutuhkan, karena pemikiran ini mengutamakan kerukunan di antara perbedaan, dan membuka diri dengan pemikiran-pemikiran baru. Oleh karenanya, dalam hal ini sedikit menyinggung terkait dengan epistemologi Islam yang secara koheren merupakan bagi yang tidak terpisahkan dari metodologi studi Islam.

Penulisan ini menjadi penting ketika tantangan secara akademik dilancarkan oleh Helmut Schmidr yang mengatakan bahwa agama, menurut pengalaman Eropa adalah musuh nomor satu demokrasi, pluralisme dan egalitarianisme. Schmidr mengatakan bahwa Eropa Barat ingin menegakkan demokrasi dan pluralisme dengan terlebih dahulu harus menyudahi peran agama dalam politik. Schimdr, dalam pengakuan sendiri sangat mengagumi Pancasila, namun ia sangat ingin

\footnotetext{
${ }^{10}$ Fazlur Rahman, Gelombang Perubahan dalam Islam Studi tentang Fundamentalisme Islam, terj. Aam Fahmia (Jakarta: Rajawali Press, 2001), 9.

${ }^{11}$ Yusuf HM, "Teologi Pluralitas", 70.
} 
tahu bagaimana rekonsialisi sila pertama (yang menurutnya adalah agama) dengan sila keempat (yang menurutnya adalah demokrasi). ${ }^{12}$

\section{Tinjauan Epistemologi Islam}

Secara spesifik, dalam membedah kajian jenis pengetahuan memiliki ciri-ciri yang umum digunakan, yaitu apa (ontologi), bagaimana (epistemologi), dan untuk apa (aksiologi) pengetahuan tersebut disusun. ${ }^{13}$ Dari ketiga dasar filosofis inilah yang merupakan sumber derivasi paradigma keilmuan, secara tersusun memiliki paradigmatik masing-masing yang konsekuensinya terwujud dalam body of knowledge pengetahuan. Untuk itu, epistemologi adalah salah satu cabang pokok bahasan dalam wilayah filsafat yang memperbincangkan seluk beluk pengetahuan. ${ }^{14}$

Epistemologi adalah salah satu cabang filsafat yang membahas tentang hakikat pengetahuan manusia. Persoalan pokok yang berkembang dalam epistemologi adalah meliputi sumber-sumber pengetahuan, watak dari pengetahuan manusia, apakah pengetahuan itu valid atau tidak. Bagaimana pengetahuan manusia itu didapat, dengan cara apa dan apa saja syarat-syarat yang harus dipenuhi, sehingga epistemologi sampai pada problem hubungan metodologi dengan objek dari ilmu pengetahuan. ${ }^{15}$

Posisi sentral epistemologi adalah tentang kajian mengenai apa yang dapat diketahui, serta bagaimana cara mengetahuinya. ${ }^{16}$ Epistemologi bermaksud mengkaji dan mencoba menemukan ciri-ciri umum dan hakikat dari pengetahuan manusia, bagaimana pengetahuan itu diperoleh dan diuji kebenarannya. ${ }^{17}$ Singkatnya, epistemologi adalah pengetahuan mengenai pengetahuan yang juga sering disebut "teori pengetahuan (theory of knowledge)". Surajiyo secara lebih rinci menyatakan bahwa pokok bahasan epistemologi adalah

\footnotetext{
12 Ibid., 71

13 Jujun S. Suriasumantri, Filsafat Ilmu: Sebuah Pengantar Populer (Jakarta: Pustaka Sinar Harapan, 1983), 105.

${ }^{14}$ Muhammad Muslih, Filsafat Ilmu: Kajian atas Asumsi Dasar, Paradigma, dan Kerangka Teori Ilmu Pengetahuan (Yogyakarta: Belukar, 2008), 7.

15 Kaelan M.S, Metode Penelitian Kualitatif Bidang Filsafat: Paradigma Bagi Pengembangan Penelitian Interdisipliner Bidang Filsafat, Budaya, Sosial, Semiotika, Sastra, Hukum, dan Seni (Yogyakarta: Paradigma, 2005), 36.

16 Suparlan Suhartono, Filsafat Ilmu Pengetahuan (Yogyakarta: Ar-Ruzz Media, 2008), 117.

${ }_{17}$ Sudarminta, Epistemologi Dasar: Pengantar Filsafat Pengetahuan (Yogyakarta: Kanisius, 2002), 18.
} 
meliputi hakikat dan sumber pengetahuan, metode memperoleh pengetahuan, dan kriteria kasahihan pengetahuan. ${ }^{18}$

Dalam lingkungan studi Islam, istilah epistemologi sering dipertukarkan dengan istilah pemikiran. Pemikiran berasal dari kata pikir yang berarti akal budi, ingatan, angan-angan, sehingga pemikiran berarti proses, cara, perbuatan memikir. Dalam Kamus Besar Ilmu Pengetahuan, pikiran berarti suatu entitas yang memperlihatkan fungsifungsi seperti mencerap, mengamati, mengingat memungkinkan manusia merefleksikan dunia objektif ke dalam tataran konsep, putusan dan teori lewat proses abstraksi, analisis, sintesis, pemecahan dan hipotesis. ${ }^{19}$ Menurut Michel Foucault, pemikiran berarti pemahaman dan pandangan seseorang terhadap suatu objek (kenyataan). Pemahaman tersebut meliputi apa yang dianggap penting dan tidak penting, hubungan apa yang diadakan antara berbagai unsur kenyataan dalam penggolongan dan analisis, dan lain sejenisnya. ${ }^{20}$

Sedangkan makna dari Epistemologi Islam adalah ilmu pengetahuan, ílm al-ílm. Mempelajari asal-usul, hakikat dan metode sebuah ilmu pengetahuan dengan tujuan mendapatkan keyakinan. Epistemologi Islam, naz̧arîyat al-ma'rifah al-Islâmîyah, didasarkan pada paradigma tauhid. Parameter tetapnya adalah dari wahyu. Parameter tidak tetapnya disesuaikan oleh keadaan waktu dan tempat yang bervariasi. Sumbernya adalah wahyu (al-Qur'ân dan al-Sunnah), observasi dan percobaan empiris, serta alasan kemanusiaan. Sekarang ini tantangan utamanya adalah meraih objektivitas dan istikamah, yaitu tetap pada jalan kebenaran dan tidak dapat digoyahkan oleh tingkah laku dan hawa nafsu. Istikamah hanya datang setelah iman, seperti sabda Rasulullah qul amant bi Allab thumm istaqim. ${ }^{21}$

Dalam pemikiran Islam, secara historis para filsuf Muslim telah membahas epistemologi yang diawali dengan membahas sumber-

\footnotetext{
18 Surajiyo, Filsafat Ilmu dan Perkembangannya di Indonesia (Jakarta: Bumi Aksara, 2008), 26.

19 Save. M. Dagun, Kamus Besar Ilmu Pengetahuan (Jakarta: Lembaga Pengkajian Kebudayaan Nusantara (LPKN), 1997), 847.

${ }^{20}$ Johan Meuleman, "Kata Pengantar", dalam Mohammed Arkoun, Nalar Islami dan Nalar Modern: Berbagai Tantangan dan Jalan Baru, terj. Rahayu S. Hidayat (Jakarta: INIS, 1994), 21-22.

21 Omar Hasan Kasule, "Epistemologi Islam dan Integrasi Ilmu Pengetahuan pada Universitas Islam: Epistemologi Islam dan Proyeksi Reformasi Kurikulum", makalah disampaikan pada seminar yang diselenggarakan oleh Universitas Muhammadiyah Makassar, Sabtu, 7 Februari 2009, 1.
} 
sumber pengetahuan yang berupa realitas. Realitas dalam epistemologi Islam tidak hanya terbatas pada realitas fisik, tetapi juga mengakui adanya realitas yang bersifat nonfisik, baik berupa realitas imajinal (mental) maupun realitas metafisika murni. ${ }^{22}$ Mengenai alat pencapaian pengetahuan, para pemikir Islam secara umum sepakat ada tiga alat epistemologi yang dimiliki manusia untuk mencapai pengetahuan, yaitu; indera, akal, dan hati. Berdasarkan tiga alat tersebut, maka terdapat tiga metode pencapaian pengetahuan, yaitu: a) metode observasi sebagaimana yang dikenal dalam epistemologi Barat, atau juga disebut metode bayânî yang menggunakan indera sebagai pirantinya, b) metode deduksi logis atau demonstratif (burhânî) dengan menggunakan akal, dan c) metode intuitif atau 'irfânî dengan menggunakan hati. ${ }^{23}$

Menurut Miska M. Amien, epistemologi Islam membahas masalah-masalah epistemologi pada umumnya dan juga secara khusus membicarakan wahy dan ilhâm, sebagai sumber pengetahuan dalam Islam. ${ }^{24}$ Wahyu hanya diberikan Allah kepada para nabi dan rasul melalui Malaikat Jibril, dan berakhir pada Nabi Muhammad. ${ }^{25}$ Wahyu hanya khusus untuk para nabi, karena ia merupakan konsekuensi kenabian dan kerasulan. ${ }^{26}$ Ilham adalah inspirasi atau pancaran ilahi yang ditiupkan ruh suci ke dalam hati nabi atau wali. ${ }^{27}$ Inspirasi atau intuisi pada prinsipnya dapat diterima setiap orang. ${ }^{28}$ Oleh karena itu, di satu sisi epistemologi Islam berpusat pada Allah sebagai sumber pengetahuan dan kebenaran, tetapi di sisi lain, epistemologi Islam berpusat pada manusia sebagai pelaku pencari pengetahuan (kebenaran).

Oleh karena itu, bahasan epistemologi Islam, menurut M. Amin Abdullah, bahwa dalam wacana filsafat Islam, wilayah metafisika, epistemologi, dan etika menyatu dalam bentuk mistik (mysticism). Aspek yang lebih menarik dikaji lebih dalam dari ketiga ranah tersebut

\footnotetext{
${ }^{22}$ Mulyadhi Kartanegara, Panorama Filsafat Islam (Bandung: Mizan, 2002), 58.

23 Ibid., 63.

${ }^{24}$ Miska M. Amien, Epistemologi Islam (Jakarta: UI Press, 1983), 1-10.

25 Amatullah Amstrong, Khazanah Istilah Sufi: Kunci Memasuki Dunia Tasawnf, terj. Nasrullah dan Ahmad Baiquni (Bandung: Mizan, 1996), 312-313.

${ }^{26}$ Mulla Sadra, Iksîr al-'Arifin (Tokyo: Jami’ah Tokyo, 1984), 124.

27 Amstrong, Khazanah Istilah Sufi, 112.

28 Jumantoro dan Syamsul Munir, Kamus Ilmu Tasawnf (Wonosobo: Amza, 2005), 86.
} 
adalah hubungan antara "mistisisme" dan "epistemologi". ${ }^{29}$ Di sinilah urgensi dari epistemologi Islam, karena secara dinamis dari zaman ke zaman telah dilakukan upaya pemaduan atau harmonisasi antara mistisisme dan filsafat dalam rangka mencapai pengetahuan hakiki, sehingga muncul berbagai paradigma dalam epistemologi Islam.

\section{Teologi Pluralistik: Sebuah Tradisi Baru?}

Dalam perdebatan mengenai teologi, intelektual Muslim sepakat bahwa kekuatan akal atau rasio mutlak sangat dibutuhkan, walaupun tanpa mengesampingkan wahyu Tuhan, karena bagaimana pun untuk memahami teks agama yang begitu kompleks tidak saja dibutuhkan rasio, tetapi wahyu sangat dibutuhkan. Perpaduan wahyu dan rasio bagi pemikiran Islam merupakan satu kesatuan yang tidak dapat dipisahkan. Hal ini bagaikan dua sisi mata pisau yang tajam dalam pengembangan aspek ilmu pengetahuan.

Dalam falsifikasi ilmu, perpaduan antara wahyu dan rasio merupakan salah satu aplikasi dari paradigma kritis. Dimana paradigma ini menjadi acuan dalam berpikir bagi seorang ilmuwan Muslim. Sebagaimana penerapan paradigma kritis, ilmuwan Muslim kontemporer Ḥasan Hanafî terlihat jelas dalam konstraksi pemikirannya terhadap agama. Dalam mempengaruhi masyarakat Islam yang mengalami ketertinggalan, hal pertama yang dilakukan adalah menganalisis dengan analisa sosial. Menurutnya, selama ini Islam mengandalkan otoritas teks dan nash al-Qur'ân dalam kenyataan. Hanafî menemukan kelemahan mendasar dalam memecahkan problem ketertinggalan, yaitu metodologi. Metodologi yang digunakan Islam selama ini lebih bersifat tradisional teks sebagai ideologi. Untuk itu, dalam memecahkan problematika tersebut, secara terbuka harus memberikan kritik tajam terhadap metode tradisional tersebut. $^{30}$

Dalam mengembalikan peran agama sebagai jawaban atas problem sosial, Hanafî mencoba menggunakan metode kritik Islam. Metode ini merupakan pendefinisian realitas secara konkret untuk mengetahui siapa memiliki apa, agar realitas berbicara dengan sendirinya. Sebagai realisasi dari metode ini, Hanafî menawarkan desentralisasi ideologi dengan cara menjalankan teologi sebagai

29 M. Amin Abdullah, Islamic Studies di Perguruan Tinggi: Pendekatan IntegratifInterkonektif (Yoyakarta: Pustaka Pelajar, 2006), 14-15.

${ }^{30}$ Hassan Hanafi, Oksidentalisme: Sikap Kita terhadap Tradisi Barat, terj. M. Najib Buchori (Jakarta: Paramadina, 2000), 81. 
antropologi. Pikiran ini dimaksudkan untuk menyelamatkan Islam agar tidak semata-mata menjadi sistem kepercayaan (teologi parexellence), melainkan juga sebagai sistem pemikiran.

Usaha yang ditempuh Ḥanafî untuk meyakinkan bahwa Islam juga sebagai sistem pemikiran adalah dengan melakukan rekonstruksi terhadap teologi tradisional, di mana teologi tradisional telah mengalami pembekuan hingga perlu memasukan metode hermeneutik dan ilmu sosial lain sebagai bagian integral dari teologi. Upaya ini dapat menjelaskan teologi menjadi antropologi, hal ini dimaknai teologi sebagai ilmu kalam. Kalam merupakan realitas manusia sekaligus Ilahi. Kalam bersifat manusiawi karena merupakan wujud verbal dari kehendak Tuhan ke dalam bentuk manusia dan bersifat Ilahi karena datang dari Tuhan.

Refleksi hermeneutik menjadi penting bila kita berhubungan dengan manusia yang pengalaman-pengalamannya tidak selalu dapat dipilahpilah dalam kategori, tidak dapat digolongkan, maupun tidak dapat dipelajari secara artifisial. Juga sering terjadi bahwa yang dibutuhkan oleh bermeneutik adalah pengetahuan tentang manusia atau masyarakat yang diperoleh bukan atas dasar kerja ilmiah, melainkan hanya dapat dipelajari sebagai suatu seni. Hal tersebut berarti, setiap bermenent memulai dari sebuah teori yaitu Teori Kondisi Manusiawi. HansGeorg Gadamer menyatakan:

"Dalam refleksi hermeneutik tentang syarat-syarat pemahaman, nyatalah bahwa kemungkinan-kemungkinan menyatakan diri dalam kesadaran yang merumuskan pemahaman dalam sebuah bahasa tidak mulai dari nol atau berakhir dalam ketidaktentuan. Model filsafat praktis ini harus mampu berfungsi sebagai theoria yang legitimasi ontologisnya hanya dapat ditemukan di dalam Intellectus Infinitus (pemikiran yang luas) yang tidak dikenal dalam pengalaman eksistensial karena tidak didukung oleh wahyu". ${ }^{31}$

Gadamer menyediakan ruang untuk wahyu atau suatu bentuk intuisi yang tidak boleh berlaku dalam metodologi. Mungkin yang menjadi salah satu karena Filsafat Timur atau mistik tidak pernah benar-benar mencapai tingkatan pengakuan universal adalah kenyataan bahwa filsafat tersebut berhubungan dengan kebenaran, dengan mempergunakan metode satupun selain menyembunyikan pengalaman-pengalaman yang tidak dapat ditembus oleh penelitian logika. Namun, cara supralogika tersebut bukan dimaksudkan untuk

31 E. Sumaryono, Hermeneutika: Sebuah Metode Filsafat (Yogyakarta: Kanisius, 1999), 79. 
mencapai suatu kebenaran eksistensial melalui pengalaman eksistensial. Oleh karena itu, berfilsafat tidak mulai dari titik nol, tetapi harus berpikir dan berbicara dengan bahasa yang sudah kita miliki sendiri. Maka, pernyataan bahwa filsafat itu sepenuhnya bebas prasangka adalah naif. Filsafat tidak mulai dari suatu tempat tertentu, tidak dari titik awal yang sudah bersifat subjektif, personal maupun dengan suatu perspektif tertentu. Menurut Gadamer, filsafat hermeneutik memahami dirinya sendiri bukan sebagai posisi mutlak sebuah pengalaman, melainkan sebagai jalan pengalaman itu. Ini menegaskan tidak ada prinsip yang lebih tinggi daripada mengusahakan diri tetap terbuka untuk berbicara dengan orang lain. ${ }^{32}$

Dalam pandangan lain, kalam merupakan kajian yang lebih bersifat praktis daripada logis. Pandangan teologi ini tentu saja berbeda dengan teologi Islam secara tradisioal yang dimengerti sebagai akidah yang benar. Kritik ini banyak orang yang berpandangan bahwa teologi sebagai ilmu akidah yang benar disebut dengan Mutakallimûn atau 'abl al-ra'y wa al-nazar dan abl al-bid'ah. Kedua kelompok ini pada gilirannya berhadapan secara dialektis, yang lebih mengedepankan kata-kata tetapi bukan tindakan.

Gagasan teologi sebagai antropologi sebenarnya ingin menempatkan ilmu kalam sebagai ilmu tentang dialektika. Dialektika tersebut mengisyaratkan untuk kepentingan orang-orang yang beriman dalam masyarakat tertentu. Selain itu, teologi menjadi antropologi merupakan cara ilmiah untuk mengatasi ketersinggungan teologi itu sendiri. Cara ini dilakukan untuk membebaskan manusia agar tidak terbelenggu dalam ruang ke-jumudan. Upaya yang tampak secara provokatif yang dilakukan ilmuwan kontemporer Muslim, terlintas dalam beberapa artikel Ḥanafî yang diberi judul "Ideologi dan Pembangunan" dengan subjudul dari tuhan ke bumi, dari keabadian ke waktu, dari takdir ke kehendak bebas, dan dari otoritas ke akal, dari teologi ke tindakan, dari karisma ke partisipasi massa, dari jiwa ke tubuh, dari eskatologi ke futurologi. ${ }^{33}$

Dalam kajian lain, teologi pluralistik didasarkan pada kajian dialektis antara esoterisme dan eksoterisme. Dialektika pemikiran tersebut pada dasarnya bertujuan untuk membawa manusia menuju peradaban perdamaian dalam pluralitasnya. Esoterisme dan

\footnotetext{
32 Ibid., 80.

${ }^{33}$ Hassan Hanafi, Islam in the Modern World (Kairo: The Anglo-Egyptian Bookshop, 1995), 142.
} 
eksoterisme merupakan dua dimensi keagaman yang tidak bisa dipisahkan. Wilayah esoterik ibarat hati, dan wilayah eksoterik adalah raga agama. Wilayah eksoterik merupakan aspek luar dari agama yang berbentuk, formal, dogmatik, ritual, dan etik. Sedangkan, wilayah esoterik adalah inti dari agama. ${ }^{34}$

Bagian esoterik sifatnya lebih sakral dan ketetapan hukum Tuhan sebagaimana manusia sebagai hamba Tuhan yang senantiasa tunduk dan patuh. Namun, bagian eksoterik merupakan bagian kajian-kajian yang sifatnya profan, di mana dimensi agama bisa didialogkan, dengan rasa hormat dan harmoni. Maka eksoterik bersifat relatif bukan memiliki kepastian mutlak, karena kebenaran sejati dan absolute tidak mungkin ditemukan hanya dalam sebuah bentuk. Kebenaran yang diungkapkan pasti memiliki bentuk tentu, dan dari segi metafisik mustahil suatu bentuk mesti memuat semua nilai kebenaran yang dapat meniadakan bentuk-bentuk lainnya.

Dalam menjelaskan yang sifatnya profan itu tidak ada kebenaran yang sifatnya mutlak (absolut), karena yang mutlak hanya yang Tak Terbatas. Dengan demikian, eksoterisme yang relatif sudah seharusnya memiliki keterbukaan dalam memandang kebenarankebenaran yang ada dalam bentuk lain. Namun pada dimensi yang lain, eksoterisme harus mewaspadai persoalan otokrasi dan eksklusivisme, karena sifat-sifat itulah yang cenderung mengarah pada kehidupan yang intoleran, disharmoni, destruktif, dan konflik antar atau intra-umat beragama.

Pada titik inilah, menurut M. Fethullah Gülen menyerukan gerakan-gerakan sosial keagamaan dengan penuh kasih sayang dan menawarkan agama cinta sebagai solusi atas lahirnya radikalisme, hegemoni penguasa, sentralistik, dan penindasan. Dari perspektif eksoterisme ini Gülen menawarkan konstruksi pemikiran yang lebih mengedepankan toleran yang dikemas dalam dialog dan pendidikan inklusif. $^{35}$

Dengan demikian, pemikiran teologi pluralistik merupakan wacana intelektual yang dapat dijadikan model bagaimana aplikasi tindakan keagamaan diberlakukan dalam wilayah keberagaman. Namun, perlu digarisbawahi pemikiran Islam tersebut berbeda dengan

\footnotetext{
34 Seyyed Hossein Nasr, (ed.), The Essential of Frithjof Schuon (Bloomington: Indiana World Wisdom, 2005), 15.

${ }_{35}$ Muhammed Fethullah Güllen, Toward a Global Civilizationof Love and Tolerance, terj. Mehmet Unal dkk (New Jersey: Tugra Book, 2009), 71-74.
} 
cara berpikir kritis Barat yang hanya berdasarkan pada semangat revolusioner sekuler dan dorongan kepentingan sebagai dasar pijakan. Kajian ini mendorong masyarakat Muslim Indonesia agar tidak terjebak dalam dogmatisme agama yang dijadikan nilai-nilai kehidupan di era kekinian. Selain itu, ada upaya mendorong agar lebih kritis dengan bersikap melawan belenggu yang kadang dikarenakan oleh pemahaman distoritf.

Berpikir kritis ala Barat tidak kemudian dihapuskan begitu saja, tetapi hanya dijadikan sebagai alat dan metode analisa, bangunan teoretis, dan semangat pembebasan yang terkandung di dalamnya. Karena itu, wacana inklusif dalam pemahaman keagamaan bila dijalankan oleh warga Muslim Indonesia, maka kehidupan keagaman akan berjalan dinamis, demokratis, dan penguatan civil society akan segara terwujud. Tentu saja hal ini dapat mewujud dengan baik manakala dipahami secara mendalam pengertian, kerangka paradigmatik, dan konsep teoretis dari teologi pluralistik yang dibangun.

Bagi masyarakat Muslim Indonesia yang majemuk, pandangan ini tidak cukup dengan melakukan transformasi sosial, karena hal itu hanya berhenti pada dataran metodologis-konseptual untuk mewujudkan masyarakat komunikatif dan sikap kritis dalam memandang realitas. Namun, dengan berpandangan yang open minded diharapkan mampu menelanjangi berbagai tendensi ideologi, memberikan perspektif kritis dalam wacana agama dan sosial, serta memberikan perspektif perubahan pasca-masyarakat terbebaskan.

Dalam mengkaji manusia Indonesia sebagai interpretandum atau objek yang ditafsirkan, tidaklah mumgkin melepaskan kajian ini terhadap bagaimana falsafah bangsa Indonesia memandang Manusia Indonesia. Notonagoro yang menjelaskan Manusia Indonesia adalah manusia adalah makhluk monopluralis, yaitu pertama, berdasarkan kedudukan kodrat manusia Indonesia yang terdiri dari sebagai makhluk pribadi berdiri sendiri sekaligus sebagai makhluk Tuhan; kedua, berdasarkan susunan kodrat manusia Indonesia yang terdiri dari unsur raga dan unsur jiwa; ketiga, berdasarkan sifat kodratnya, manusia Indonesia yang terdiri dari unsur individual dan unsur sosial. ${ }^{36}$

Notonagoro dengan menggunakan teori causalis menyatakan bahwa keberadaan Pancasila bagi bangsa Indonesia dapat dipertang-

36 Notonagoro, Pancasila Ilmiah Populer (Jakarta: CV. Pantjuran Tudjuh, 1971), 94105. 
gungjawabkan secara ilmiah. Causa materialis Pancasila adalah adat kebiasaan, kebudayaan, dan agama bangsa Indonesia. Causa formalisnya adalah formulasi Pancasila yang tercantum dalam Pembukaan UUD 1945. Causafinalis adalah dasar negara. Adapun causaefficien Pancasila adalah dasar filsafat negara. Berdasarkan teori causalis itu pula, dalam analisis ilmiah tentang hakikat dan hubungan antara Tuhan Yang Maha Esa dengan manusia, Notonagoro berkesimpulan bahwa Tuhan Yang Maha Esa itu merupakan causa prima, motor immobilis, sangkan paraningdumadi. Sementara itu hakikat manusia sebagai makhluk Tuhan Yang Maha Esa tersusun monopluralis, sarwa tunggal (jiwa-tubuh, individu-sosial, laki-perempuan, dan sebagainya) yang dalam keseluruhan dan keutuhannya beraktivitas dalam rangka pemenuhan kebutuhan kemanusiaannya yang mengarah pada kesempurnaan (absolut, mutlak). ${ }^{37}$ Menurut Roeslan Abdoelgani, dalam Pancasila tercapailah keseimbangan nilai rohani dan jasmani dari manusia Indonesia. ${ }^{38}$

Cara berpikir seperti demikian tentu akan merupakan hal asing bagi ilmuwan hukum saat ini. Terhadap hal tersebut, Bernard Arief Sidharta menegaskan bahwa titik tolak pandangan hidup bangsa Indonesia adalah keyakinan bahwa manusia itu diciptakan dalam kebersamaan dengan sesamanya; individu dan kesatuan pergaulan hidupnya (masyarakat) merupakan suatu kedwitunggalan. Jadi kebersamaan dengan sesamanya atau pergaulan hidup itu adalah unsur hakiki dalam eksistensi manusia. Unsur raga, rasa, dan rasio bersamasama mewujudkan aspek individualisme dari manusia, dan unsur rukun mewujudkan aspek sosialitas dari manusia; aspek individualisme dan aspek sosialitas tersebut merupakan suatu kesatuan yang tidak dapat dipisahkan yang satu dari yang lainnya. ${ }^{39}$

Asas kerukunan atau "rukun", menurut Soediman Kartodiprodjo, merupakan alat pelengkapan bagi manusia, selain raga, rasa, dan rasio

\footnotetext{
${ }^{37}$ Sudjito, "Pancasila Sebagai Dasar Filsafat dan Paradigma Ilmu Hukum", Makalah ini disampaikan dalam Konferensi Nasional Ke-3 Asosiasi Filsafat Hukum Indonesia dengan tema Melampaui Perdebatan Positivisme Hukum dan Teori Hukum Kodrat yang diselenggarakan oleh AFHI bekerjasama dengan Epitema Institute dan Fakultas Hukum Universitas Airlangga, tanggal 27-28 Agustus 2013, 5.

38 Sunoto, Mengenal Filsafat Pancasila: Pendekatan melalui Metafisika, Logika, dan Etika (Yogyakarta: Hanindita Graha Widya, 1995), 51.

${ }^{39}$ Bernard Arief Sidharta, Refleksi tentang Struktur Ilmu Hukum: Sebuab Penelitian tentang Fondasi Kefilsafatan dan Sifat Keilmuan Ilmu Hukum sebagai Landasan Pengembangan Ilmu Hukum Nasional Indonesia (Bandung: Mandar Maju, 2009), 173-174.
} 
dalam kehidupan berkelompok, dan tidak sebagai makhluk yang terpisah satu sama lain, dan kemudian karena sesuatu hal ingin hidup bersama berdasarkan asas kekeluargaan yang merupakan inti jiwa dari Pancasila. Dalam konteks asas kerukunan tersebut, dikarenakan hidup berkelompok itu baru ada manfaatnya kalau hidup dengan rukun, maka alat perlengkapan manusia ini hendak dinamakan unsur rukun dalam kehidupan manusia. Dengan demikian, manusia itu terdiri dari empat unsur ini, yakni: raga, rasa, rasio dan rukun. Dengan asas kerukunan inilah manusia akan mencapai kebahagiaan dalam kehidupannya. Kalau manusia Indonesia melihat tujuan hidup manusia adalah hidup bahagia. Caranya, mencari jalan untuk sampai hidup bahagia itu. Jalan mempergunakan alat-alat perlengkapan hidupnya adalah cara musyawarah untuk mufakat. Cara musyawarah atau mufakat ini sebagai cara memperoleh kebahagiaan mengandung arti, diakui adanya atau mungkin adanya perbedaan antara manusia yang hidup berkelompok itu dalam mencari jalan yang menuju ke hidup bahagia tadi. Mengakui adanya perbedaan ini berarti mengakui adanya perbedaan dalam kepribadian masing-masing manusia yang berkelompok itu. Dengan tidak menyatakan bahwa salah seorang akan menguasai (pendapat) orang-orang lainnya, melainkan harus diadakan muyawarah dan mufakat, maka menurut pemikiran bangsa Indonesia itu kepribadian individu, tidak saja diakui, tetapi pula dilindungi. ${ }^{40}$

Maka dari itu, teologi pluralistik merupakan upaya melakukan kritik yang mampu mewujudkan perubahan sosial. Paradigma ini dijadikan sebagai elemen dasar, instrumen metodologi, dan kerangka konseptual (framework knowledge) dalam melakukan transformasi sosial. Oleh karenanya, kertas kerja ini dipilih sebagai upaya menjembatani kekurangan-kekurangan yang ada pada wilayah kritis sebagai bacaan terhadap realitas. Dengan demikian, kesatuan konseptual tersebut merupakan bahan yang tersusun menjadi satu. Artinya, hal itu dapat membawa realitas sosial dengan komprehensif, baik secara filosofis hingga praksis.

\section{Memaknai Kembali Teologi Pluralistik dalam Tindakan}

Epistemologi merupakan kajian yang tidak dapat dipisahkan dalam makna pencarian ilmu pengetahuan, karena hal ini menjadi kajian yang sangat penting tentang bagaimana ilmu itu didapat,

40 Achmad Suhardi Kartodiprodjo, et.al, Prof Mr. Soedirman Kartodiprodjo tentang Pancasila sebagai Pandangan Hidup Bangsa Indonesia (Bandung/Jakarta: t.tp., 2009), 5760. 
bagaimana implikasinya, dan bagaimana memaknai ilmu pengetahuan. Epistemologi bagian dari kajian filsafat yang fundamental, karena menyoal tentang suatu tema secara signifikan tentang hakikat pengetahuan dan kebenarannya. Pada gilirannya, ia menjadi sebuah wacana eksistensi makna tentang realitas sosial. ${ }^{41}$

Realitas merupakan kenyataan faktual tentang masyarakat; negara, bangsa, dan agama. Ketiga instrumen tersebut menjadi kajian tidak terpisahkan dalam sebuah dinamika pengetahuan kontemporer yang membutuhkan alat dan metode untuk memecahkan persoalan yang menyelimutinya. Sekelumit persoalan yang terjadi dalam realitas sosial dalam pemaknaannya setiap orang memiliki kaca pandang yang berbeda. Dalam pengetahuan filsafat modern, hal ini disebut dengan nalar kiritis Islam. Falsifikasi ini, menurut Arkoun, merupakan fenomena biasa yang menjadi fitrah diri manusia, karena manusia adalah makhluk sosial yang diberikan akal. ${ }^{42}$

Islam memandang dan mengakui bahwa sumber kekuatan utama pengetahuan dari Allah, dan Ia memberikan kekuatan-kekuatan pengetahuan kepada manusia. ${ }^{43}$ Sumber kekuatan ini menjadi wahyu yang diturunkan Allah melalui Malaikat Jibril kepada Nabi Muhammad untuk umat manusia. Setelah menjadi wahyu, ia menjadi petunjuk dengan merujuk kepada konsep tauhid yang bersumber dari al-Qur'ân sebagai sumber epistemologi Islam. ${ }^{44}$

Al-Qur'ân banyak digunakan untuk memaknai tentang kemasyarakatan. Menurut M. Quraish Shihab, konteks al-Qur'ân tersebut seperti sebutan qawm, ummah, shu'úb, dan qabâil. Dengan kata lain, sifat-sifat kemasyarakatan dalam al-Qur'ân, misalkan al-mala', almustakbirûn, al-mustad'afûn, dan lain-lain. ${ }^{45}$ Dalam dimensi lain, alQur'ân menjadi sumber hukum-hukum yang mengatur masyarakat

41 Ali Harb, Nalar Kritis Islam Kontemporer, terj. Umar Bukhory (Yogyakarta: IRCiSoD, 2012), 123.

42 Muhammed Arkoun, Nalar Islami dan Nalar Modern: Berbagai Tantangan dan Jalan Baru, terj. Rahayu S. Hidayat (Jakarta: INIS, 1997), 81-83.

43 Nurcholis Madjid, "Pandangan Dunia al-Qur'ân Ajaran tentang Harapan kepada Allah dan Seluruh Ciptaan", dalam Ahmad Syafi'i Ma'arif dan Sa'id Tuhu Lelet, alQur'ân dan Tantangan Modernitas (Yogyakarta: SIPRESS, 1993), 8.

44 Eko Prasetyo, Islam Kiri: Melawan Kapitalisme Modal dari Wacana menuju Gerakan (Yogyakarta: Pustaka Pelajar, 2002), 13.

${ }^{45}$ M. Quraish Shihab, Membumikan al-Qur'ân: Fungsi dan Peran Wabyu dalam Kebidupan Masyarakat (Bandung: Mizan, 1998), 246. 
baik secara individu maupun kelompok, konteks ini menjadi sunatullah yang populer dalam Q.S. al-Ra'd [13]: 11.

Dengan demikian, dalam makna epistemologi Islam, al-Qur'ân sebagai kekuatan intelektual yang dilakukan oleh para ilmuwan Muslim yang menekankan kepada kejiwaan dan kerohanian ketimbang kebendaan dan ekonomi. Pada gilirannya, makna epistemologi Islam lebih menekankan pada nilai-nilai akhlak dan rasionalistas dengan prinsip religius dan teologis.

Maka dari itu, dalam memahami fenomena sosial masyarakat seperti kekerasan atas nama agama, sejatinya berbanding terbalik dengan spirit pengetahuan Islam yang lebih teologis. Dalam konteks ini, sedikitnya ada empat faktor dalam membangun sebuah tatanan masyarakat yang majemuk dengan jatuh bangun, di antaranya; keadilan dan kezaliman (Q.S. al-Qașaș [28]: 4), persatuan dan perpecahan (Q.S. al-An'âm [6]: 153), pengamalan dan pelecehan prinsip amr ma'rûf naby munkar (Q.S. al-Mâidah [5]: 79), dan kebobrokan moral (Q.S. Hûd [11]: 116). ${ }^{46}$

Dalam masyarakat Indonesia yang sangat beraneka ragam coraknya, kemauan dan kemampuan mengendalikan diri dan kepentingan adalah suatu sikap yang mempunyai arti yang sangat penting dan bahkan merupakan sesuatu yang sangat diharapkan untuk menumbuhkan keseimbangan dan stabilitas masyarakat. Pandangan sosial yang berdiri di atas paham keseimbangan tidaklah mengingkari bahwa masyarakat itu senantiasa bergerak berubah dan berkembang karena sifat masyarakat yang dinamis. Karena itu, pangkal tolak penglihatan dan pengamalan Pancasila adalah kemauan dan kemampuan manusia Indonesia dalam mengendalikan diri agar dapat melaksanakan kewajibannya sebagai warga negara dan warga masyarakat. ${ }^{47}$

Konseptindakan dalam berbuat terhadap manusia lain, dalam Islam dapat dijumpai dalam Q.S. al-Naḥl [16]: 90 menegaskan "Sesungguhnya Allah menyuruh (kamu) berlaku adil dan berbuat kebajikan”. Ditegaskan pula dalam Q.S. al-Mâidah [5]: 8 yang menjelaskan "Dan janganlah sekali-kali kebencianmu terhadap suatu kaum, mendorong kamu untuk berlaku tidak adil." Sedangkan dalam

\footnotetext{
${ }^{46}$ Munir Che Anam, Mubammad SAW dan Karl Marx Tentang Masyarakat Tanpa Kelas (Yogyakarta: t.tp., 2008), 211.

${ }^{47}$ Hartati Soemasdi, Pemikiran tentang Filsafat Pancasila (Yogyakarta: Penerbit Andi Offset, 1992), 78.
} 
hal proses peradilan, Allah memerintahkandalam Q.S al-Nisâ' [4]: 58 bahwa "Apabila kamu memutuskan perkara di antara manusia, maka hendaklah engkau memutuskannya dengan adil." Dengan demikian, konsep mengenai 'adil' dalam hukum Islam pun bersifat filosofisdogmatis-teologis.

Berdasarkan hal tersebut, Ahmad Azhar Basyir menjelaskan keadilan dalam konsep hukum Islam adalah suatu upaya meletakkan sesuatu pada tempat yang sebenarnya atau menempatkan sesuatu pada proporsinya yang tepat dan memberikan kepada seseorang sesuatu yang menjadi haknya. ${ }^{48}$ Oleh karena itu, dalam konsep hukum Islam berbuat adil terhadap orang lain adalah merupakan suatu perbuatan yang sangat dianjurkan bahkan melalui Q.S. al-Baqarah [2]: 148, ditegaskan perbuatan baik merupakan suatu perlombaan atau fa istabiq al-khayrât (berlomba-lombalah dalam kebajikan).

Konsep teologis tersebut merupakan konsep dasar dalam memahami manusia Indonesia; sebuah pemahaman yang mengedepankan perbuatan baik sebagai suatu penilaian terhadap keadilan bagi orang lain memunculkan konsep penghargaan terhadap eksistensi orang lain dan menumbuhkan kesadaran diri akan eksistensinya dalam suatu kelompok yang bersifat komunal. Penghargaan terhadap nilai-nilai yang hidup sebagai suatu bentuk perbuatan baik terhadap manusia lain, pada akhirnya akan menciptakan suatu konsep kerukunan yang mampu mempersatukan masing-masing individu dalam ruang lingkup kehidupannya. Pemahaman terhadap berbuat baik tersebut merupakan gerakan melingkar tanpa henti antara individu dalam meneropong masyarakat dan masyarakat dalam meneropong individu.

Sebagai pengaturan perilaku selain untuk mewujudkan ketertiban dan keteraturan dalam masyarakat, hukum juga dimaksudkan untuk mewujudkan asas keadilan. Karena itu, hukum diarahkan untuk memberikan kepada setiap orang apa yang menjadi bagiannya sesuai dengan jasa atau apa yang telah diberikannya; memberikan perlakuan yang sama menurut proporsinya, memberikan imbalan sesuai dengan kecakapan dan jasanya terhadap masyarakat, dan memberikan hukuman sesuai dengan kesalahannya. Kesemuanya ini adalah akibat yang timbul dari kenyataan bahwa keberadaan manusia dikodratkan berstruktur ada-bersama-dengan-sesamanya (ada dalam kebersamaan

\footnotetext{
48 Abdul Aziz Dahlan (ed.), Ensiklopedia Hukum Islam, Vol. 2 (Jakarta: Ichtiar Baru van Hoeve, 1997), 25.
} 
dengan sesamanya). Karena manusia dikodratkan ada bersama dengan sesamanya dalam masyarakat, maka manusia tidak dapat mengelakkan diri dari keberadaan dalam pergaulan dengan sesamanya. Justru karena itu ketertiban dan keteraturan dalam masyarakat yang dikehendaki (yang manusiawi) adalah yang tidak kaku, yang semata-mata hanya berdasarkan perhitungan untung-rugi saja, yang (dapat) mewujudkan ketertiban yang menekan perkembangan kemanusiaan. ${ }^{49}$

Yang dikehendaki adalah ketertiban dan keteraturan yang bersuasana ketenteraman batin, kesenangan bergaul di antara sesamanya, keramahan dan kesejahteraan yang memungkinkan terselenggaranya interaksi antar-manusia yang sejati. Hukum yang dijiwai oleh Pancasila adalah hukum yang berasaskan semangat kerukunan. Karena hukum secara langsung diarahkan untuk mewujudkan keadilan sosial yang memberikan kepada masyarakat sebagai kesatuan dan masing-masing warga masyarakat kesejahteraan (material dan spiritual) yang merata dalam keseimbangan yang proporsional. Terpaut pada asas kerukunan adalah asas kepatutan. Asas ini juga adalah asas tentang cara menyelenggarakan hubungan antar-warga masyarakat yang di dalamnya para warga masyarakat diharapkan untuk berperilaku dalam kepantasan yang sesuai dengan kenyataan-kenyataan sosial.

Para warga masyarakat diharapkan untuk memperhatikan kepantasan, yakni dari para warga masyarakat diharapkan berperilaku sedemikian rupa hingga tidak merendahkan martabatnya sendiri dan atau orang lain. Sifat lain yang memberikan ciri pada hukum Pancasila adalah asas keselarasan. Asas ini menghendaki terselenggaranya harmoni dalam kehidupan bermasyarakat. Berdasarkan asas ini, penyelesaian masalah-masalah konkret selain harus didasarkan pada pertimbangan kebenaran dan kaidah-kaidah hukum yang berlaku juga harus dapat diakomodasikan pada proses-proses kemasyarakatan sebagai keseluruhan yang utuh dengan mempertimbangkan perasaanperasaan yang sungguh-sungguh hidup dalam masyarakat. Para warga masyarakat dan pelaksana hukum diharapkan patut dalam melaksanakan hak dan kewajibannya, sehingga kerukunan dan kesejahteraan bermasyarakat dapat dipertahankan dan dikembangkan. Asas kerukunan, asas kepatutan dan asas keselarasan sebagai ciri-ciri khas dari hukum Pancasila dapat dicakup dengan satu istilah, yakni

\footnotetext{
49 Bernard Arief Sidharta, Filsafat Hukum Pancasila (Bandung: Universitas Parahyangan, 2009), 4.
} 
sifat kekeluargaan. Dapat dikatakan hukum Pancasila adalah hukum dengan semangat kekeluargaan. Semangat kekeluargaan menunjuk pada sikap yang berdasarkannya kepribadian setiap warga masyarakat diakui dan dilindungi oleh masyarakat. ${ }^{50}$

Manusia tidak dapat membebaskan diri dari kecenderungan dasarnya untuk memberikan makna, yang oleh Merleu Ponty disebut Man is condemned to meaning. Dunia alam material ini menjadi dunia manusiawi karena diberi makna manusiawi oleh manusia dan hal tersebut tercipta melalui penafsiran. Memberi makna adalah sama dengan memahami (verstehen). Menurut Wilhelm Dilthey, bila seseorang dipahami dengan pengertian tentang manusia universal, hal ini menyebabkan kita harus melakukan pengalaman ulang atas hubungan-hubungan batin dari manusia universal ke masing-masing ungkapan individual. Sedangkan untuk dapat memahami orang lain dan ungkapan-ungkapan hidupnya, maka pemahaman terhadap diri sendiri adalah mutlak. Pemahaman terhadap geisteswissenschaften tergantung kepada pengalaman-pengalaman batin kita, yaitu pengalaman yang tidak dapat dijangkau oleh metode ilmiah. ${ }^{51}$ Dengan demikian, menurut F. Budi Hardiman, bahwa objek penelitian ilmuilmu sosial-kemanusiaan tidak diketahui lewat introspeksi, melainkan lewat interpretasi. Untuk meninggalkan Schleiermacher, Wilhelm Dilthey memusatkan modelnya pada "hubungan timbal balik dari penghayatan (Erleben), ungkapan (Ausdruck) dan pemahaman (Verstehen). ${ }^{52}$

Berdasarkan hal tersebut, teologis pluralisme dalam perspektif Pancasila sebagai dasar dari cara kerja hermeneutike untuk mencapai suatu penilaian terhadap keadilan adalah membutuhkan pemahaman yang melibatkan pengalaman dari si penafsir. Sebagaimana diungkapkan oleh Jürgen Habermas bahwa untuk mencapai pemahaman, hermeneutik harus mengintegrasikan tiga model ekspresi kehidupan, yaitu linguistik, tindakan, dan pengalaman. Ketiganya harus diintegrasikan ke dalam pemahaman hermeneutik. ${ }^{53}$ Pandangan dari Habermas tersebut hampir memiliki kemiripan dengan pandangan Gadamer yang menegaskan setiap pemahaman senantiasa merupakan suatu yang bersifat historis, peristiwa dialektis, dan

50 Ibid., 5.

${ }^{51}$ Sumaryono, Hermeneutika, 51.

52 Richard E. Palmer, Hermeneutika: Teori Baru Mengenai Interpretasi, terj. Masnur Heri dan Damanhuri Muhammad (Yogyakarta: Pustaka Pelajar, 2005), 120.

53 Sumaryono, Hermeneutika, 91. 
peristiwa kebahasaan. Namun, menurut E. Sumaryono, pandangan dari Harbermas tersebut dari pendapat Dilthey. ${ }^{54}$ Maka terbukalah kemungkinan terciptanya bermeneutika yang lebih luas. Kunci dari pemahaman (verstehen) adalah partisipasi dan keterbukaan bukan manipulasi dan pengendalian. Menurut Hans-GeorgGadamer, bermeneutika berkaitan dengan pengalaman bukannya pengetahuan, berkaitan dengan dialektika bukan metodologi..$^{55}$ Oleh karena itu, makna keadilan dalam perspektif Pancasila melalui metode hermeneutika mengandung kebenaran intersubjektivitas.

Berdasarkan prinsip-prinsip tersebut di atas, jika dicerna kembali, masih ditemukan konsep-konsep kajian Islam yang menjadi sumber pengetahuan kelompok Muslim dalam tindakannya yang menekankan kekerasan dan mencederai makna amr ma'rûf naby munkar. Sejatinya, ada sesuatu yang salah dalam memaknai pengetahuan Islam. Karena itu, realitas sosial yang menyuguhkan tindakan kekerasan atas nama Tuhan seyogianya tidak koheren dengan kajian Islam yang lebih menekankan akhlak dan lebih teologis.

Apabila masih ditemukan kelompok-kelompok masyarakat yang sangat fundamentalis dalam memaknai fenomena sosial, hampir dipastikan mereka belum menemukan hakikat kebenaran ilmu pengetahuan yang bersumber dari al-Qur'ân. Karena sumber epistemologi Islam yang mengacu pada wahyu yang kemudian diinterpretasikan dalam bentuk-bentuk ijtihad para ilmuwan atau ulama, selalu menekankan hakikat perdamaian, ketenangan, ketenteraman, kemaslahatan, khayr al-ummah, mutamaddin, dan lain-lain.

\section{Penutup}

Indonesia sudah semestinya menjadi role model dunia tentang kemajemukan, pluralisme, modernitas, dan kedamaian. Walaupun berbeda-beda suku, bahasa, agama, dan ras, Indonesia masih meneguhkan diri dengan bingkai Bineka Tunggal Ika dengan falsafah Pancasila.

Sebagai falsafah bangsa, Pancasila yang menghargai keragaman telah ternodai oleh kelompok masyarakat yang mengatasnamakan Islam. Namun, Islam yang mereka pahami tidak berbanding lurus dengan Islam yang telah dirumuskan oleh para ulama terdahulu, sehingga lahir statemen ḥubb al-watan min al-îmân. Dengan kondisi ini,

\footnotetext{
${ }^{54}$ Ibid., 92.

${ }^{55}$ Kaelan M.S., Filsafat Bahasa: Semiotika dan Hermeneutika (Yogyakarta: Paradigma, 2009), 285.
} 
tentu perlu dicerna, didefiniskan, bahkan diinterpretasikan kembali makna dan hakikat pengetahuan Islam yang lebih menekankan nilainilai akhlak dan ketauhidan.

Sedikitnya ada empat faktor dalam membangun sebuah tatanan masyarakat yang majemuk dengan jatuh bangun, di antaranya; keadilan dan kezaliman (Q.S. al-Qaṣaṣ [28]: 4), persatuan dan perpecahan (Q.S. al-An'âm [6]: 153), pengamalan dan pelecehan prinsip amr ma'rûf naby munkar (Q.S. al-Mâidah [5]: 79), dan kebobrokan moral (Q.S. Hûd [11]: 116). Bila disepakati bahwa kemajemukan dalam kedamaian merupakan fitrah, maka harus dimaknai kembali apa yang dimaksud dengan ketauhidan sebagaimana yang diajarkan oleh Nabi Muhammad.

\section{Daftar Rujukan}

Abdullah, M. Amin. "Ide Pembaruan dalam Filsafat Islam", dalam Mengenang Y.B. Mangunwijaya Pergulatan Intelektual dalam Era Kegelisahan. Yogyakarta: Kanisius, 2003.

-----. Islamic Studies di Perguruan Tinggi: Pendekatan Integratif-Interkonektif. Yoyakarta: Pustaka Pelajar, 2006.

Amien, Miska M. Epistemologi Islam. Jakarta: UI Press, 1983.

Amstrong, Amatullah. Khazanah Istilah Sufi: Kunci Memasuki Dunia Tasawnf, terj. Nasrullah dan Ahmad Baiquni. Bandung: Mizan, 1996.

Anam, Munir Che. Mubammad SAW dan Karl Marx Tentang Masyarakat Tanpa Kelas. Yogyakarta: t.tp., 2008.

Arkoun, Muhammed. Nalar Islami dan Nalar Modern: Berbagai Tantangan dan Jalan Baru, terj. Rahayu S. Hidayat. Jakarta: INIS, 1997.

Dagun, Save. M. Kamus Besar Ilmu Pengetahuan. Jakarta: Lembaga Pengkajian Kebudayaan Nusantara (LPKN), 1997.

Dahlan, Abdul Aziz (ed.). Ensiklopedia Hukum Islam, Vol. 2. Jakarta: Ichtiar Baru van Hoeve, 1997.

Güllen, Muhammed Fethullah. Toward a Global Civilizationof Love and Tolerance, terj. Mehmet Unal dkk. New Jersey: Tugra Book, 2009.

Hanafi, Hassan. Islam in the Modern World. Kairo: The Anglo-Egyptian Bookshop, 1995.

----. Oksidentalisme: Sikap Kita terhadap Tradisi Barat, terj. M. Najib Buchori. Jakarta: Paramadina, 2000.

Harb, Ali. Nalar Kritis Islam Kontemporer, terj. Umar Bukhory. Yogyakarta: IRCiSoD, 2012. 
Jumantoro dan Munir, Syamsul. Kamus Ilmu Tasawuf. Wonosobo: Amza, 2005.

Karim, Khalil Abdul. "Problematika Pemikiran Islam Kontemporer: Studi Kritis Atas Buku "Solusi Islam; Keharusan dan Keniscayaan Karya Dr. Yusuf Al-Qardlawi”, dalam Afkar Taswbirul Jurnal Refleksi Pemikiran Kegamaan dan Budaya, Edisi No. 9 Tahun 2000.

Kartanegara, Mulyadhi. Panorama Filsafat Islam. Bandung: Mizan, 2002. Kartodiprodjo, Achmad Suhardi et.al. Prof Mr. Soedirman Kartodiprodjo tentang Pancasila sebagai Pandangan Hidup Bangsa Indonesia. Bandung/Jakarta: t.tp., 2009.

Kasule, Omar Hasan. "Epistemologi Islam dan Integrasi Ilmu Pengetahuan pada Universitas Islam: Epistemologi Islam dan Proyeksi Reformasi Kurikulum”, makalah disampaikan pada seminar yang diselenggarakan oleh Universitas Muhammadiyah Makassar, Sabtu, 7 Februari 2009.

M.S, Kaelan. Filsafat Babasa: Semiotika dan Hermeneutika. Yogyakarta: Paradigma, 2009.

-----. Metode Penelitian Kualitatif Bidang Filsafat: Paradigma Bagi Pengembangan Penelitian Interdisipliner Bidang Filsafat, Budaya, Sosial, Semiotika, Sastra, Hukum, dan Seni. Yogyakarta: Paradigma, 2005.

Madjid, Nurcholis. "Pandangan Dunia al-Qur'ân Ajaran tentang Harapan kepada Allah dan Seluruh Ciptaan", dalam Ahmad Syafi'i Ma'arif dan Sa'id 'Tuhu Lelet, al-Qur'ân dan Tantangan Modernitas. Yogyakarta: SIPRESS, 1993.

-----. Islam, Doktrin, dan Peradaban: Sebuah Telaah Kritis tentang Masalab Keimanan, Kemanusiaan, dan Kemodernan. Jakarta: Paramadina, 2000.

Meuleman, Johan. "Kata Pengantar", dalam Mohammed Arkoun, Nalar Islami dan Nalar Modern: Berbagai Tantangan dan Jalan Baru, terj. Rahayu S. Hidayat. Jakarta: INIS, 1994.

Mujahidin, Anwar. "Epistemologi Islam: Kedudukan Wahyu sebagai Sumber Ilmu", Ulumuna: Jurnal Studi Keislaman, Vol. 17, No. 1, 2013.

Muslih, Muhammad. Filsafat Ilmu: Kajian atas Asumsi Dasar, Paradigma, dan Kerangka Teori Ilmu Pengetahuan. Yogyakarta: Belukar, 2008.

Nasr, Seyyed Hossein (ed.). The Essential of Frithjof Schuon. Bloomington: Indiana World Wisdom, 2005.

Notonagoro. Pancasila Imiah Populer. Jakarta: CV. Pantjuran Tudjuh, 1971. 
Palmer, Richard E. Hermeneutika: Teori Baru Mengenai Interpretasi, terj. Masnur Heri dan Damanhuri Muhammad. Yogyakarta: Pustaka Pelajar, 2005.

Prasetyo, Eko. Islam Kiri: Melawan Kapitalisme Modal dari Wacana menuju Gerakan. Yogyakarta: Pustaka Pelajar, 2002.

Rahman, Fazlur. Gelombang Perubahan dalam Islam Studi tentang Fundamentalisme Islam, terj. Aam Fahmia. Jakarta: Rajawali Press, 2001.

-----. Islam. Chicago: The University of Chicago Press, 1979.

Roswantoro, Alim. "Epistemologi Pemikiran Islam M. Amin Abdullah", dalam Islam, Agama-agama, dan Nilai Kemanusiaan. Yogyakarta: CISForm, 2013.

Sadra, Mulla. Iksîr al-'Ârifinn. Tokyo: Jami’ah Tokyo, 1984.

Shihab, M. Quraish. Membumikan al-Qur'ân: Fungsi dan Peran Wabyu dalam Kebidupan Masyarakat. Bandung: Mizan, 1998.

Sidharta, Bernard Arief. Filsafat Hukum Pancasila. Bandung: Universitas Parahyangan, 2009.

Sidharta, Bernard Arief. Refleksi tentang Struktur Ilmu Hukum: Sebuah Penelitian tentang Fondasi Kefilsafatan dan Sifat Keilmuan Ilmu Hukum sebagai Landasan Pengembangan Ilmu Hukum Nasional Indonesia. Bandung: Mandar Maju, 2009.

Soemasdi, Hartati. Pemikiran tentang Filsafat Pancasila. Yogyakarta: Penerbit Andi Offset, 1992.

Sudarminta. Epistemologi Dasar: Pengantar Filsafat Pengetahuan. Yogyakarta: Kanisius, 2002.

Sudjito. "Pancasila Sebagai Dasar Filsafat dan Paradigma Ilmu Hukum", Makalah ini disampaikan dalam Konferensi Nasional Ke-3 Asosiasi Filsafat Hukum Indonesia dengan tema Melampani Perdebatan Positivisme Hukum dan Teori Hukum Kodrat yang diselenggarakan oleh AFHI bekerjasama dengan Epitema Institute dan Fakultas Hukum Universitas Airlangga, tanggal 27-28 Agustus 2013.

Suhartono, Suparlan. Filsafat Ilmu Pengetabuan. Yogyakarta: Ar-Ruzz Media, 2008.

Sumaryono, E. Hermeneutik: Sebuah Metode Filsafat. Yogyakarta: Kanisius, 1999.

Sunoto. Mengenal Filsafat Pancasila: Pendekatan melalui Metafisika, Logika, dan Etike. Yogyakarta: Hanindita Graha Widya, 1995. 
Surajiyo. Filsafat Ilmu dan Perkembangannya di Indonesia. Jakarta: Bumi Aksara, 2008.

Suriasumantri, Jujun S. Filsafat Ilmu: Sebuah Pengantar Populer. Jakarta: Pustaka Sinar Harapan, 1983.

Yusuf HM, Muh. "Teologi Pluralis Multikultural: Perspektif Qurani”, Jurnal Kontekstualitas, Vol. 24, No. 2, 2008. 